5. Тероризм як засіб дестабілізації державної влади // Актуальні проблеми державно-правового розвитку України в контексті євроінтеграційних процесів : матеріали міжнарод. наук.-практ. конф., присвяч. 20-річчю Конституції України; м. Запоріжжя, 23-24 червня 2016 р. / редкол.: С.К. Бостан (відпов. ред.), Р.М. Максакова, Ю.В. Філей.Запоріжжя : Просвіта, 2016. С. 460-463.

6. Гуляєв В.П. Тероризм як загроза сучасного суспільства / В.П. Гуляєв. URL: http://www.nbuv.gov.ua/old_jrn/soc_gum/domtp/2010_1/Gyljaev.pdf.

7. Хміль Г.А. Природний, техногенний та екологічний ризики: аналіз, оцінка, управління / Г.А. Хміль. URL: http://pidruchniki.com/72385/ ekologiya/prirodniy_tehnogenniy_ta_ekologichniy_ riziki_analiz_otsinka_upravlinnya.

8. Про Службу безпеки України : Закон України від 25 березня 1992 року № 2229-XII. URL: http://zakon3.rada.gov.ua/laws/show/2229-12.

9. Про засади внутрішньої та зовнішньої політики : Закон України від 1 липня 2010 року № 2411-VI. URL: https://zakon.rada.gov.ua/laws/show/2411-17.

10. Методи і засоби виконання завдань СБУ. URL: https:// ssu.gov.ua/ua/pages/38.

11. Про телекомунікації : Закон України від 18 листопада 2003 року № 1280-IV // Відомості Верховної Ради. 19 березня 2004 р. № 12. Ст. 155.

12. Кримінальний процесуальний кодекс України : Закон України від 13 квітня 2012 року станом на 7 жовтня 2014 року // Офіиійний сайт Верховної Ради Украӥни. URL: http://zakon2.rada.gov.ua.

УДК 343.611

DOI https://doi.org/10.32844/2618-1258.2019.6.51

СКОК С.Г.

\title{
ДО ПИТАННЯ ПРО КВАЛІФІКАЦІЮ УМИСНИХ ВБИВСТВ У РАЗІ КОНКУРЕНЦІЇ КРИМІНАЛЬНО-ПРАВОВИХ НОРМ
}

У статті досліджено особливості кваліфікації умисних вбивств у разі конкуренції кримінально-правових норм та конкретизовано, що конкуренція кримінально-правових норм є нормальною ознакою кодифікованого законодавства і свідчить про урахування законодавцем типових, але значною мірою специфічних ознак злочинних проявів, і засвідчує виділення конкретизованих норм із більш загальних норм, якими встановлена відповідальність за злочин, виписаний законодавцем у загальному (типовому) вигляді. Наявність у КК України двох або більше норм, спрямованих на захист одних і тих же об'єктів, є їх конкуренцією. Якщо злочин передбачено загальною і спеціальною нормами, сукупність злочинів відсутня, і кримінальна відповідальність настає за спеціальною нормою. Прикладом спеціальної норми щодо ст. 115 КК України (умисне вбивство) як загальної норми може бути ст. 379 КК України (посягання на життя судді, народного засідателя чи присяжного у зв'язку з їхньою діяльністю, пов'язаною зі здійсненням правосуддя). 3'ясовано, що аналіз судово-слідчої практики показує, що умисне вбивство, вчинене у стані сильного душевного хвилювання, або умисне вбивство у випадку перевищення меж необхідної оборони або в разі перевищення заходів, необхідних для затримання злочинця, також іноді вчиняються з особливою жорстокістю, також мають характер особливого мучення. Зроблено висновок про те, що якщо у скоєному діянні наявні дві або більше кваліфікуючі ознаки, то всі вони повинні бути згадані в обвинуваченні і вироку суду. Вчинені дії в такому випадку не утворюють сукупності злочинів, оскільки у скоєному діянні мають місце лише ознаки одного одиничного злочину. Наявність декількох кваліфікуючих ознак має враховуватися під час призначення покарання, посилюючи його. Отже, наявність двох або більше

(C) СКОК С.Г. - здобувач (Науково-дослідний інститут публічного права) 
кваліфікуючих ознак у вчиненому вбивстві має бути відображено в обвинуваченні і вироку суду. Не дивлячись на відсутність сукупності злочинів у вчиненому діянні, наявність декількох кваліфікуючих ознак все ж має враховуватися під час визначення тяжкості вчиненого і призначення покарання. У кожному конкретному діянні необхідно виявляти мотиви та цілі вчинення злочину, щоб виключити норми, які конкурують.

Ключові слова: злочин, покарання, життя людини, умисне вбивство, множинність, повторність, сукупність, рецицив.

The article investigates the peculiarities of the qualification of premeditated murders in the competition of criminal law norms and concludes that the competition of criminal law norms is a normal feature of the codified legislation and indicates that the legislator takes into account typical, but to a large extent, specific signs of criminal manifestations and certifies rules that establish responsibility for a crime, written out by the legislator in a general (typical) form. The presence in the Criminal Code of Ukraine of two or more norms aimed at protecting the same objects is their competition. If a crime is stipulated by general and special norms, the aggregate of crimes is absent and criminal liability comes by a special norm. An example of a special rule for Art. 115 of the Criminal Code of Ukraine (premeditated murder), as a general rule, may be Art. 379 of the Criminal Code of Ukraine (encroachment on the life of a judge, judge or jury in connection with their activities related to the administration of justice). It has been found that the analysis of the case-law shows that premeditated murder was committed in a state of intense emotional disturbance or premeditated murder in excess of the limits of necessary defense or in case of exceeding the measures necessary to apprehend the offender. torture. It is concluded that if there are two or more qualifying features in the act, they must all be mentioned in the prosecution and sentencing. The act committed in this case does not constitute a set of crimes, since in the act committed there are only signs of one single crime. The presence of several qualifying attributes should be taken into account when imposing a sentence, reinforcing it. Therefore, the presence of two or more qualifying signs in the murder must be reflected in the prosecution and sentencing. In spite of the absence of a set of crimes in the act, the presence of several qualifying signs should nevertheless be taken into account in determining the gravity of the offender and the imposition of punishment. In each specific act, the motives and goals of the crime must be identified in order to exclude competing rules.

Key words: crime, punishment, human life, premeditated murder, multiplicity, repetition, totality, relapse.

Постановка проблеми. Вчинення однією особою двох і більше злочинів свідчить про більш високий ступінь суспільної небезпеки як самого суб'єкта, так і вчинених ним злочинних діянь. Під час вчинення особою декількох злочинів, як правило, заподіюється більша моральна, фізична або матеріальна шкода суспільству і окремим громадянам. У множинній злочинній діяльності проявляється антигромадська спрямованість особи винного, його небажання дотримуватися встановлених у суспільстві законів.

У чинному кримінальному законодавстві України правила кваліфікації злочинів взагалі і кваліфікації множинності злочинів зокрема не передбачені. Однозначно, такі правила існують, вони вироблені кримінально-правовою наукою і апробовані практикою. Проте пропозиція про доцільність закріплення в КК самостійного розділу, в якому такі правила були б зафіксовані, яка висловлювалась неодноразово в юридичній літературі, так і залишилась не сприйнятою законодавцем.

Стан дослідження. Не отримала комплексного вирішення проблема кваліфікації множинності злочинів і в юридичній літературі. В Україні на монографічному рівні вона не досліджувалась. Водночас немає підстав стверджувати, що такі питання не досліджувались взагалі. Окремі аспекти цієї проблеми піднімались українськими та зарубіжними вченими під час розгляду декількох блоків кримінально-правових проблем. Зокрема, І.Б. Агаєв, Н.Б. Алієв, М.І. Бажанов, М.І Блум, А.С. Горелік, В.К. Грищук, П.С. Дагель, І.О. Зінченко, Ю.О. Красіков, Г.Г. Криволапов, В.П. Малков, Д.М. Молчанов, Н.Д. Дурманов, А.С. Нікіфоров, Р.Б. Пєтухов, А.А. Піонтковський, 
Ф.Р. Рагімов, М.М. Становський, А.А. Стрижевська, Н.А. Стручков, Г.Т. Ткешеліадзе, В.І. Тютюгін, П.Л. Фріс, Ю.Н. Юшков, А.М. Яковлєв, Н.Ф. Яшинова частково розглядали питання кваліфікації під час дослідження множинності злочинів у межах питань Загальної частини кримінального права.

Виклад основного тексту. Визначаючи співвідношення між сукупністю злочинів та конкуренцією кримінально-правових норм, необхідно встановити, чи охоплюється вчинене положеннями однієї кримінально-правової норми і чи не становлять вчинені діяння більшої суспільної небезпеки, ніж передбачено відповідною нормою. У разі якщо ці правила порушено, діяння повинні утворювати сукупність злочинів.

Вищевикладене дає підстави стверджувати, що у випадку відмежування ідеальної сукупності від конкуренції «частини» $\mathrm{i}$ «цілого» визначальною ознакою $є$ повнота опису в диспозиції конкретної статті вчиненого діяння. Ця ознака подібна до тієї, що розмежовує складений злочин і ідеальну сукупність. Таким чином, видається, що під час розмежування ідеальної сукупності злочинів і складеного злочину застосовується правило конкуренції «частини» $\mathrm{i}$ «цілого». Якщо загальне правило діє, то вчинене утворює складений злочин, у разі неможливості застосування цього правила діяння кваліфікується як ідеальна сукупність злочинів.

Про існування в теорії кримінального права проблеми визначення поняття «конкуренція» говорять давно. Найбільші проблеми виникають під час розмежування термінів «конкуренція» та «колізія».

Слід погодитися з Маріним О.К., який вважає, що єдиною спільною ознакою колізії та конкуренції кримінально-правових норм $є$ подвійне (потрійне та ін.) нормативне регулювання одного й того ж суспільного відношення [1, с. 77].

Кваліфікація вбивства як одиничного злочину найчастіше ускладнюється тим, що один злочин у багатьох випадках підпадає під ознаки декількох норм одночасно або декількох частин однієї і тієї ж норми, що утворює конкуренцію кримінально-правових норм.

Конкуренція кримінально-правових норм $є$ нормальною ознакою кодифікованого законодавства і свідчить про урахування законодавцем типових, але значною мірою специфічних ознак злочинних проявів і засвідчує виділення конкретизованих норм із більш загальних норм, якими встановлена відповідальність за злочин, виписаний законодавцем у загальному (типовому) вигляді. Наприклад, умисне вбивство, передбачене п. 8 ч. 2 ст.115 КК України, і посягання на життя, передбачене ст. 400 КК України. Співвідношення цих норм показує, що в основі конкуренції лежить їх логічне співвідношення за обсягом і змістом. На підставі співвідношення за обсягом визначаються принципи конкуренції загальної і спеціальної норми, а також двох спеціальних норм.

Щоб відмежувати загальну і спеціальну норми, необхідно правильно використати загальний методологічний підхід у співвідношенні загального і одиничного. Спеціальній нормі природно притаманні всі ознаки загальної норми, але вона має і свої специфічні риси, за якими вона може бути відмежована від загальної. Слідчо-судова практика свідчить про складність та припущення помилок під час вирішення цих завдань.

В окремих випадках вчинене може підпадати під ознаки від двох до шести, а то й більше пунктів ч. 2 ст. 115 КК і у зв'язку не тільки з мотивом, але й ціллю вчиненого вбивства і навіть засобом зазіхання.

Так, під час вчинення умисного вбивства основною ціллю є бажання позбавлення життя людини, що виступає загальною спрямованістю зазіхання. Конкретизуючими її є користь, (під час виконання вбивства на замовлення), приховування іншого злочину або полегшення його вчинення, протидія законним вимогам та ін. Такі цілі можуть визватись як одним, так і декількома мотивами, що не суперечать один одному. До вчинення вбивства можуть збуджувати декілька мотивів, що відносяться до однієї і тієї ж сфери певних відносин, що і повинно розкриватися під час конкретизації мети злочину. Суміщення різнорідних мотивів неможливе, особливо у випадку вчинення злочинів, що можуть співвідноситися в різноманітних варіантах між собою і бути при цьому несумісними з тими, що не торкаються особистих інтересів і не пов'язані з ними. Такими $\epsilon$ хуліганські мотиви у вигляді протидії законній діяльності осіб, що виконують службовий або громадський обов'язок, тощо.

Мотиви вчинення умисних вбивств у зв'язку з виконанням потерпілим свого громадського або службового обов'язку можуть мати різний зміст, хоча вони викликаються його суспільно-корисною діяльністю або пов'язані з їі виконанням. Співвідношення таких мотивів із хуліганськими відтворюється під час зазіхання на життя працівника правоохоронного органу або громад- 
ського формування у зв'язку з його діяльністю з охорони публічного порядку. Відповідальність за такий злочин передбачена у ст. 348 КК України. У зв'язку із цим слід зазначити, що згадані злочини мають власний мотив у вигляді прагнення протидії законній діяльності потерпілих із охорони громадського порядку або помсти за таку діяльність. Цей злочин співвідноситься з хуліганськими мотивами як під час переростання хуліганства в більш небезпечний злочин, так і під час вчинення двох самостійних злочинів, в яких здійснюється замах на два різноманітні безпосередні об'єкти - громадський порядок і порядок управління, що свідчить про сукупність або конкуренцію норм, за якої питання про конкуренцію норм вирішується на користь більш небезпечного одиночного злочину, що, на наш погляд, не зовсім вірно. У таких випадках сукупність злочинів не повинна виключатись або замінюватись. Порушується принцип відповідальності за вчинений злочин у повному обсязі. До того ж такі норми можуть бути найбільш ефективними тільки тоді, коли їх диспозиції будуть містити в собі сукупність тих злочинних дій, що більше і частіше всього зустрічаються на практиці, розділившись між собою, навіть і у цифровому перерахуванні пунктів, як це передбачається в новому Кримінальному кодексі.

У теорії кримінального права розроблені загальнотеоретичні передумови кваліфікації злочинів у випадку конкуренції норм, проте багато питань цієї теми ще не вирішені.

Як вже було сказано, наявність у КК України двох або більше норм, спрямованих на захист одних і тих же об'єктів, є їх конкуренцією. Якщо злочин передбачено загальною і спеціальною нормами, сукупність злочинів відсутня, і кримінальна відповідальність настає за спеціальною нормою. Прикладом спеціальної норми щодо ст. 115 КК України (вбивство), як загальної норми, може бути ст. 379 КК України (посягання на життя судді, народного засідателя чи присяжного у зв'язку з їхньою діяльністю, пов'язаною зі здійсненням правосуддя). Загальна (родова) і спеціальна (видова) норми не будуть утворювати сукупності злочинів, оскільки містять ознаки одного й того ж діяння. У подібних випадках для правильної кваліфікації діяння необхідно вибрати ту 3 конкуруючих норм, яка найбільш правильно описує основні характеристики діяння, відображає його суттєві властивості. Відповідно до п. 20 постанови Пленуму Верховного Суду України № 2 від 7 лютого 2003 року «Про судову практику у справах про злочини проти життя і здоров'я особи» умисне вбивство без кваліфікуючих ознак, передбачених ч. 2 ст. 115 КК, а також без ознак, передбачених статтями 116-118 КК, зокрема в обопільній сварці чи бійці або з помсти, ревнощів, інших мотивів, викликаних особистими стосунками винного з потерпілим, підлягає кваліфікації за ч. 1 ст. 115 КК [2, с. 45]. Таким чином, за наявності кваліфікуючих ознак вчинене діяння кваліфікується за ч. 2 ст. 115 КК України, оскільки вона є спеціальною щодо частини першої зазначеної статті. Кваліфіковані види вбивства передбачають найбільш тяжкі і суспільно небезпечні наслідки і поглинають всі інші менш тяжкі наслідки.

Незважаючи на те, що у випадку конкуренції кримінально-правових норм множинність злочинів відсутня, у практиці можуть виникати помилки, пов'язані з тим, що для правильної кваліфікації діяння необхідно вибрати саме ту з конкуруючих норм, яка найбільш правильно описує основні характеристики скоєних суспільно небезпечних дій. Кваліфікація у випадку конкуренції норм ускладнюється ще й наявністю у Кримінальному Кодексі так званих привілейованих видів вбивства.

За ст. 116 (умисне вбивство, вчинене у стані сильного душевного хвилювання), 117 (умисне вбивство матір'ю своєї новонародженої дитини) і 118 (умисне вбивство внаслідок перевищення меж необхідної оборони або в разі перевищення заходів, необхідних для затримання злочинця) КК України кваліфікуються вбивства, вчинені за пом'якшуючих обставин. Постанова Пленуму Верховного Суду України № 2 від 7 лютого 2003 року «Про судову практику у справах про злочини проти життя і здоров'я особи» містить обмежену кількість роз'яснень із приводу правил кваліфікації вбивств, скоєних за наявності як обтяжуючих, так і пом'якшуючих обставин. Про конкуренцію пом'якшуючих і обтяжуючих складів злочинів умисних вбивств говоритися лише щодо умисного вбивство матір'ю своєї новонародженої дитини, а про вбивство, вчинене внаслідок перевищення меж необхідної оборони або в разі перевищення заходів, необхідних для затримання злочинця та у стані сильного душевного хвилювання, мова не йде.

Зокрема, згідно 3 п. 21 постанови Пленуму Верховного Суду України № 2 від 7 лютого 2003 року «Про судову практику у справах про злочини проти життя та здоров'я» умисне вбивство матір'ю своєї новонародженої дитини слід кваліфікувати за ст. 117 КК, якщо воно вчинене під час пологів або одразу ж після них. Вчинення цих дій через деякий час після пологів за відсутності кваліфікуючих ознак, передбачених ч. 2 ст. 115 КК, тягне відповідальність за ч. 1 зазначеної статті [2, с. 45]. 
У теорії кримінального права та судовій практиці неоднозначно вирішується питання кваліфікації умисних вбивств у стані сильного душевного хвилювання та під час перевищення меж необхідної оборони, що вчинені одночасно.

Зокрема, в одних випадках вчинення умисного вбивства під час перевищення меж необхідної оборони, коли особа одночасно перебувала у стані сильного душевного хвилювання, суди кваліфікують діяння як умисне вбивство під час перевищення меж необхідної оборони за ст. 118 КК. В інших випадках за наявності таких самих ознак вчинене кваліфікують як умисне вбивство, вчинене у стані сильного душевного хвилювання.

О.В. Авраменко із цього приводу зазначає, що, даючи відповідь на питання, яку кримінально-правову оцінку повинно отримувати вбивство, вчинене одночасно у стані сильного душевного хвилювання та під час перевищення меж необхідної оборони, якщо сильне душевне хвилювання не виключало здатність особи оцінити відповідність заподіяної нею шкоди небезпечності посягання чи обстановці захисту, слід насамперед звернутись до абзацу 1 п. 10 постанови Пленуму Верховного Суду України від 28 червня 1991 р. № 4 «Про практику застосування судами законодавства, яке забезпечує право на необхідну оборону від суспільно небезпечних посягань». Зокрема, в ньому відзначалося: «Дії осіб, які вчинили вбивство або заподіяли тяжкі тілесні ушкодження внаслідок перевищення меж необхідної оборони і одночасно перебували у стані сильного душевного хвилювання, що раптово виникло, належить кваліфікувати за статтею 97, 104 КК (1960 р.), тобто за більш м’яким законом, а не за статтями 95, 103 КК (1960 р.)». Таке роз'яснення сприяло однозначному вирішенню досліджуваного питання в судовій практиці. Проте постанова Пленуму Верховного Суду України від 26 квітня 2002 р. № 1 «Про судову практику у справах про необхідну оборону» в п. 12 наведену вище постанову від 1991 р. визнала такою, що втратила чинність. А відповідного положення щодо кваліфікації вбивств за такої ситуації чинна постанова не містить. Відсутнє положення про вирішення цього питання і в постанові Пленуму Верховного Суду України від 7 лютого 2003 р. № 2.

Із наведених вище положень можна зробити висновок, що оскільки рекомендацій щодо кваліфікації вбивства за вказаних обставин Пленумом Верховного Суду України на сьогодні не вироблено, то кваліфікувати вчинене слід, користуючись правилом, яке було зазначено в Постанові Пленуму Верховного Суду України від 28 червня 1991 р. № 4, адже, по суті, в регламентації відповідальності за вбивство, вчинене у стані сильного душевного хвилювання та під час перевищення меж необхідної оборони за чинним КК, порівняно з КК 1960 р., істотних змін немає. 2003 р. № 2. Із наведених вище положень можна зробити висновок, що оскільки рекомендацій щодо кваліфікації вбивства за вказаних обставин Пленумом Верховного Суду України на сьогодні не вироблено, то кваліфікувати вчинене слід, користуючись правилом, яке було зазначено в Постанові Пленуму Верховного Суду України від 28 червня 1991 р. № 4, адже, по суті, в регламентації відповідальності за вбивство, вчинене у стані сильного душевного хвилювання та під час перевищення меж необхідної оборони за чинним КК порівняно з КК 1960 р. істотних змін немає [3, с. 197].

Слід також зазначити, що і сьогодні санкція у ст. 118 КК України $є$ більш м'якою, ніж у ст. 116 КК України, отже, кваліфікація за ст. 118 КК відповідатиме загальним принципам призначення покарання. По-друге, необхідна оборона або затримання злочинця, на відміну від стану сильного душевного хвилювання, $є$ обставиною, що виключає злочинність діяння, що також говорить про ії пріоритетність. Стан сильного хвилювання є обставиною, яка лише пом'якшує кримінальне покарання. За таким шляхом йде і судова практика.

Якщо вбивство скоєно за наявності ознак, передбачених 118 КК України, і кваліфікуючих ознак, згаданих у ч. 2 ст. 115 КК України, то кваліфікація діяння буде залежати від обставин події. Вбивство двох або більше осіб, які вчинили злочин, залежно від їхніх дій у момент затримання може бути кваліфіковано і як правомірне діяння, і як вбивство, вчинене під час перевищення заходів, необхідних для затримання особи, яка вчинила злочин, і як кваліфіковане вбивство (п. 1 ч. 2 ст. 115 КК України). Вбивство жінки, яка завідомо для винного перебуває у стані вагітності, може бути визнано правомірним лише в разі ії крайньої небезпеки для суспільства, в іншому випадку таке діяння потрапляє під п. 2 ч. 2 ст. 115 КК України. Вбивство, вчинене способом, небезпечним для життя багатьох осіб, не може бути визнано ні правомірним, ні вчиненим під час перевищення меж необхідної оборони. Воно має кваліфікуватися за п. 5 ч. 2 ст. 115 КК України.

За ст. 118 КК України кваліфікуються випадки, які не підпадають під ознаки необхідної оборони, правомірного позбавлення життя і вбивства, передбаченого ст. 115 КК України. До них можна віднести вбивства, вчинені за наявності ознак, передбачених ст. 38 КК України. Вбивство особи, яка вчинила злочин невеликої або середньої тяжкості, не може бути кваліфіковано 
як вчинене під час перевищення заходів, необхідних для затримання, в силу невеликої суспільної небезпеки даного роду злочинів. Як вбивства, скоєні під час перевищення заходів, необхідних для затримання особи, яка вчинила злочин, фактично можуть бути кваліфіковані лише ті випадки, коли без необхідності заподіюється смерть особі, яка вчинила тяжкий або особливо тяжкий злочин, незважаючи на те, що суб'єкт, який заподіяв смерть, усвідомлював, що була і інша можливість затримання злочинця.

Не варто трактувати позначену вище позицію Верховного Суду України як рекомендацію кваліфікувати вбивство, вчинене з особливою жорстокістю, під час перевищення меж необхідної оборони, за ст. 118 КК України. Інститут необхідної оборони у кримінальному праві є однією з важливих гарантій забезпечення захисту життя, здоров'я, честі і гідності громадян, безпеки в суспільстві, інтересів держави. Відповідно до 118 КК України саме посягання з боку потерпілого і виступає підставою пом'якшення кримінальної відповідальності. I все ж повинні бути межі перевищення необхідної оборони. Для встановлення ознак перевищення меж необхідної оборони і визначення меж переростання необхідної оборони в посягання важливе значення зберігають рекомендації, що містяться в Постанові Пленуму Верховного суду України № 1 від 26 квітня 2002 р. «Про судову практику у справах про необхідну оборону». Важко уявити, що під час перевищення меж необхідної оборони неусвідомлено відбувалося б вбивство з особливою жорстокістю. Такі дії залежно від ступеня усвідомлення скоєного винним можуть кваліфікуватися або як вбивство у стані сильного душевного хвилювання, якщо вбивство з особливою жорстокістю вчиняється у відповідному стані, або як кваліфіковане вбивство, вчинене з особливою жорстокістю 3 мотивів помсти (п. 4 ч. 2 ст. 115 КК України). Виходячи із цього, можна не погодитися з Бородіним С.В., який вказує: «У тих випадках, коли винний під час вчинення вбивства внаслідок перевищення меж необхідної оборони усвідомлював чи свідомо допускав особливу жорстокість своїх дій, вони все ж потрапляють під ознаки ст. 118 КК. Справа в тому, що усвідомлення особливої жорстокості не виключає (в залежності від стану сильного душевного хвилювання) самого факту вчинення вбивства під час перевищення меж необхідної оборони» [4, с. 13]. Дійсно, усвідомлення особливої жорстокості не виключає самого факту вбивства.

Аналіз судово-слідчої практики показує, що умисне вбивство, вчинене у стані сильного душевного хвилювання, або умисне вбивство під час перевищення меж необхідної оборони або в разі перевищення заходів, необхідних для затримання злочинця, також іноді вчиняються з особливою жорстокістю, а також мають характер особливого мучення.

Зазначений спосіб вчинення злочину, передбаченого ст. 116 КК України, пояснюється тим, що винний, перебуваючи у стані сильного душевного хвилювання, потребує емоційної розрядки, тобто бажає припинити дію зовнішнього подразника, а саме протиправні дії потерпілого. При цьому емоційний стан винного значною мірою знижує його здатність усвідомлювати свої дії або керувати ними.

Тому виникає закономірне запитання: чи може вбивство у стані сильного душевного хвилювання або під час перевищення меж необхідної оборони бути скоєно з особливою жорстокістю? На нашу думку, в тих випадках, коли не встановлено, що винний, діючи у стані афекту або під час перевищення меж необхідної оборони, усвідомлює чи свідомо допускає, що він здійснює вбивство з особливою жорстокістю, злочин підлягає кваліфікації відповідно за ст. 116 або 118 КК.

Дійсно, вбивство з особливою жорстокістю може бути вчинено як свідомо, так і не усвідомлено, що й повинно впливати на кваліфікацію злочину. Вбивство, вчинене у стані сильного душевного хвилювання, безумовно, може бути скоєно з особливою жорстокістю, оскільки людина в такій ситуації перебуває у граничному, фактично неконтрольованому її свідомістю стані. Відповідно, і кваліфікація повинна бути за ст. 116 КК України. У свою чергу, усвідомлення винним особливої жорстокості говорить про підконтрольність йому скоєного злочину і, відповідно, про необхідність кваліфікації такого діяння за п. 4 ч. 2 ст. 115 КК України.

Вбивство не повинно розцінюватися як вчинене за кваліфікуючих ознак, передбачених ч. 2 ст. 115 КК України, якщо воно вчинене у стані сильного душевного хвилювання або під час перевищення меж необхідної оборони. Але за обставин, із якими зазвичай пов'язане уявлення про особливу жорстокість, навряд чи можлива кваліфікація вбивства як вчиненого під час перевищення меж необхідної оборони. Кваліфікація діяння в такому випадку повинна бути або за П. 4 ч. 2 ст. 115 КК України, як вбивства, вчиненого з особливою жорстокістю, або за ст. 116 КК України, як вбивство, вчиненого у стані сильного душевного хвилювання, залежно від ступеня усвідомлення скоєного винним. 
Важливим для розмежування вбивств, передбачених ст. ст. 115, 118 КК України, є і дійсність (реальність) наявності нападу.

Ст. 117 КК України «Умисне вбивство матір'ю своєї новонародженої дитини» встановлює, що вбивство матір'ю новонародженої дитини під час пологів або одразу ж після пологів не виключає осудності і карається обмеженням волі на строк до п'яти років або позбавленням волі на той самий строк. Склад привілейований - санкція набагато нижче, ніж у ст. 115 КК України. У період дії кримінальних кодексів союзних республік 1926-1935 р.р. лише КК УРСР 1927p. встановлював у ст. 142 самостійну відповідальність за дітовбивство, відносячи його до вбивства за пом'якшуючих обставин. Відповідальність за такі злочини в разі їх вчинення без обтяжуючих обставин наступала за ст. 103 КК УРСР. При цьому такі обставини, як особливе фізичний і психічний стан жінки під час пологів, важка сімейна обстановка, матеріальні труднощі і ін., могли враховуватися судами як пом'якшуючі. Такий злочин справедливо кваліфікувався за ст. 102 КК УРСР у разі вчинення його з особливою жорстокістю, у випадку вбивства двох і більше дітей, тобто за наявності обтяжуючих вину обставин.

Виділення вбивства матір'ю новонародженої дитини у привілейований склад у КК є цілком обгрунтованим. Стан жінки під час пологів виявляється пом'якшувальною обставиною.

Висновки. Таким чином, якщо у скоєному діянні наявні дві або більше кваліфікуючих ознаки, то всі вони повинні бути згадані в обвинуваченні і вироку суду. Вчинені дії в такому випадку не утворюють сукупності злочинів, оскільки у скоєному діянні мають місце лише ознаки одного одиничного злочину. Наявність декількох кваліфікуючих ознак має враховуватися під час призначення покарання, посилюючи його.

Отже, наявність двох або більше кваліфікуючих ознак у вчиненому вбивстві має бути відображено в обвинуваченні і вироку суду. Не дивлячись на відсутність сукупності злочинів у вчиненому діянні, наявність декількох кваліфікуючих ознак все ж має враховуватися під час визначення тяжкості вчиненого і призначення покарання. У кожному конкретному діянні необхідно виявляти мотиви та цілі вчинення злочину, щоб виключити норми, які конкурують.

\section{Список використаних джерел:}

1.Марін О.К. Кваліфікація злочинів при конкуренції кримінально-правових норм : монографія. Київ : Атіка, 2003. 224 с.

2.Постанови Пленуму Верховного Суду в кримінальному судочинстві / упорядник Вереша Р.В. Київ : Алерта, 2018. 280 с.

3.Авраменко О.В. Стан сильного душевного хвилювання за кримінальним правом України : монографія. Львів : Львівський державний університет внутрішніх справ, 2009. 244 с.

4.Бородин С.В. Преступления против жизни. Санкт-Петербург : Издательство «Юридический центр Пресс», 2003. 467 с. 